\title{
Safety Factors in Wall Thickness Calculation of Rectification Columns
}

\author{
Sanja Petronić ${ }^{1)}$ \\ Katarina Čolić ${ }^{2)}$ \\ Arko Jarić ${ }^{2)}$ \\ Nebojša Ćurčić ${ }^{1)}$ \\ Zijah Burzić ${ }^{3)}$ \\ Svetozar Sofijanić ${ }^{1)}$
}

\begin{abstract}
Gas rectification columns are a very important part of each onshore plant. Their sudden failures cause huge losses on a daily basis, while fluid leakage can be very dangerous to people and environment. For that reason, the proper design of the column is of huge importance, among the others safety factors as well. In this paper, the wall thickness measure is presented with the aim to calculate corrosion rate and remaining life of rectification columns. The minimum required column wall thickness was calculated according to the most commonly used international standard and the obtained difference was analyzed.
\end{abstract}

Key words: gas rectification columns, safety factors, corrosion rate, remaining life, thickness, NDT.

\section{Introduction}

$\mathrm{P}$ RESSURE vessel is an enclosed unit in which the pressure acts from inside or outside the enclosed volume. Due to the effect of pressure, there is a possibility that liquid or gas may leak from the vessel, which can have serious consequences for people and the environment. For this reason, the design, fabrication and testing techniques are controlled by several legislative organizations such as ASME, BS and API standards, etc. All pressure vessels used in industry must be certified by any of the legislatures.

Columns (tower) are a process apparatus in which the process of enrichment of gas or liquid, depletion of gas or liquid, or fractionation of liquid takes place, and undesirable components such as hydrogen-sulfide $\left(\mathrm{H}_{2} \mathrm{~S}\right)$, nitrogen $\left(\mathrm{N}_{2}\right)$, carbon-dioxide $\left(\mathrm{CO}_{2}\right)$, water, etc. can cause health issues, corrosion of process units, and poorer calorific values [1-4].

Safety factors provide confidence in the safe use of pressure equipment components or assemblies. Pressure equipment is potentially dangerous in nature and safety factors ensure that the risk of breakage is minimized. Many authors have studied the design of vessels from the aspect of process, occupational and environmental safety. Darlaston and Wintle 2007 [5] discusses the role of safety factors in the pressure equipment and recommends that there are three main considerations to be taken into account: technology uncertainty, human error and misadventure. Sandeep et al. (2004) [6] performed an analysis on multilayer pressure vessels taking into account different materials to reduce construction costs. They concluded that the maximum stress developed in the pressure vessel was within the yield strength of the material. Devaraju and Pazhanivel (2015) [7] studied the stress analysis on the pressure vessels taking into account the internal pressure, their own weight and the weight of the liquid and concluded that the vessel is safe. Merlin and Chitaranjan (2017) [8] studied the stresses in different types of end domes in the analysis of pressure vessels with respect to torispherical and hemispherical heads. Rashmi and Vinod (2017) [9] studied Von Mises stresses and normal stresses on vessels with a flat bottom and a hemisphere. Sadanandam et al. (2017) [10] conducted a study of the design and analysis of a pressure vessel using finite elements method. Apurva et al (2018) [11] conducted a study of the design and analysis of a pressure vessel with a focus on the analysis of the safety parameters of a pressure vessel for a given working pressure. They concluded that the maximum working pressure was considered within the permitted limit. Durgha and Sachidananda 2019 [12] reported a pressure vessel design according to ASME standards. They performed thermal analysis on the pressure vessel made up of different types of materials by varying the shell thickness of the vessel for various ambient temperature.

In this paper, the analysis of wall thickness according to different standards is performed. Although starting from the same formula, different standards take into account different degrees of safety. This is offset by more frequent inspections. Also, the inspection of gas rectification columns is presented. Wall thicknesses were measured, corrosion rates were calculated and remaining life was calculated.

\section{Safety Considerations in Columns}

In various areas of the process industry, especially in gas and oil processing plants, columns are very widely used, in

\footnotetext{
1) Department of Belgrade Polytechnic, The Academy of Applied Technical Studies Belgrade, SERBIA

2) Innovation Centre of the Faculty of Mechanical Engineering in Belgrade, SERBIA

3) Military Technical Institute (VTI), Ratka Resanovića 1, 11132 Belgrade, SERBIA

Correspondence to: Sanja Petronić, e-mail: sanjapetronic@yahoo.com
} 
which accidents occur relatively often and, in that sense, safety analyses related to their application are extremely important. Following the expansion and wider areas of the process industry application and due to a large number of processes that include various types of processing of hazardous chemicals, occupational and process safety are defined as the primary aspect. One of the main reasons for failures and accidents in columns is an inadequate design, so from an engineering point of view, it is essential to consider this aspect in order to analyze and assess the plant safety. All steps need to be taken to minimize the risk of failures and accidents, given that accidents in columns have resulted in huge losses of human lives and property. By applying the inherent safety concept, occupational and process safety risks are reduced, and to increase the safety level, numerous guidelines and procedures are developed and applied.

There are various reasons for the hazardous accidents and failure of process equipment, however, the most common and most critical cause for the safety endangerment of process equipment is the inadequate design. [13] Most often safety analyses of the plant are performed after the process design is completed, and at this stage, it is possible to control the risk only by applying passive, active and procedural strategies of the process safety, and it should be emphasized that at this stage each modification in the process requires additional large investments. The second approach involves the analysis of safety risks in the preliminary design phase, when minimization or mitigation of safety risks is possible, as well as design adjustments with less investment.

It is necessary to ensure the safest possible operation of the plant in the process industry, which ensures occupational safety and profit, and in that sense, it is essential to respect standards, regulatory and protective measures at all stages of the process. A very important issue in the process industries is accessing safety, which is provided by applying many guidelines and procedures, as well as by applying different standards, and within this paper the aspect of safety is analyzed by applying different standards on the case study example of a column. Besides, the influence of heat and mass transfer, operational conditions on the process safety and effectiveness of the protective systems have a great influence on the preservation of column safety.

It is necessary to define all the impacts and risks that can lead to safety problems in the columns, and as the most important safety factors are defined: influence of hydrodynamic and mass transfer, the effects of operational conditions on process safety, control loop stability during nonstandard operation, effectiveness of the protective systems. The analysis of the safety aspect shows that there are a significant number of safety issues in the columns and based on the reported safety problems [13], dangerous outcomes as hazardous accidents and column failures are most often associated with the equipment complexity and high material contents.

The application of dynamic modeling of the column is an efficient procedure for risk assessment, taking into account that in this way it is possible to systematically define and characterize the effect of different operational disturbances. It is necessary to define and analyze the influential factors for safety risks in the columns, which primarily include: assessment of the system protection and system optimization options, evaluation of possible malfunctions and physical effects of disturbance in the column and economic risks. In this sense, it is necessary to collect and integrate all relevant information on scenarios, frequencies and consequences that affect the overall risk assessment, which can be defined as

$$
R I S K=f(s, c, f)
$$

$S$-scenario,

$c$ - consequence,

$f$ - frequency.

\section{Case Study - Gas Rectification Columns}

The Gas Rectification Columns (presented in Figure 1) operate at a maximum temperature of $100^{\circ} \mathrm{C}$ and a pressure, Ps, of $7.9 \mathrm{MPa}$ and contain a raw gas and 30\% WT DEA.

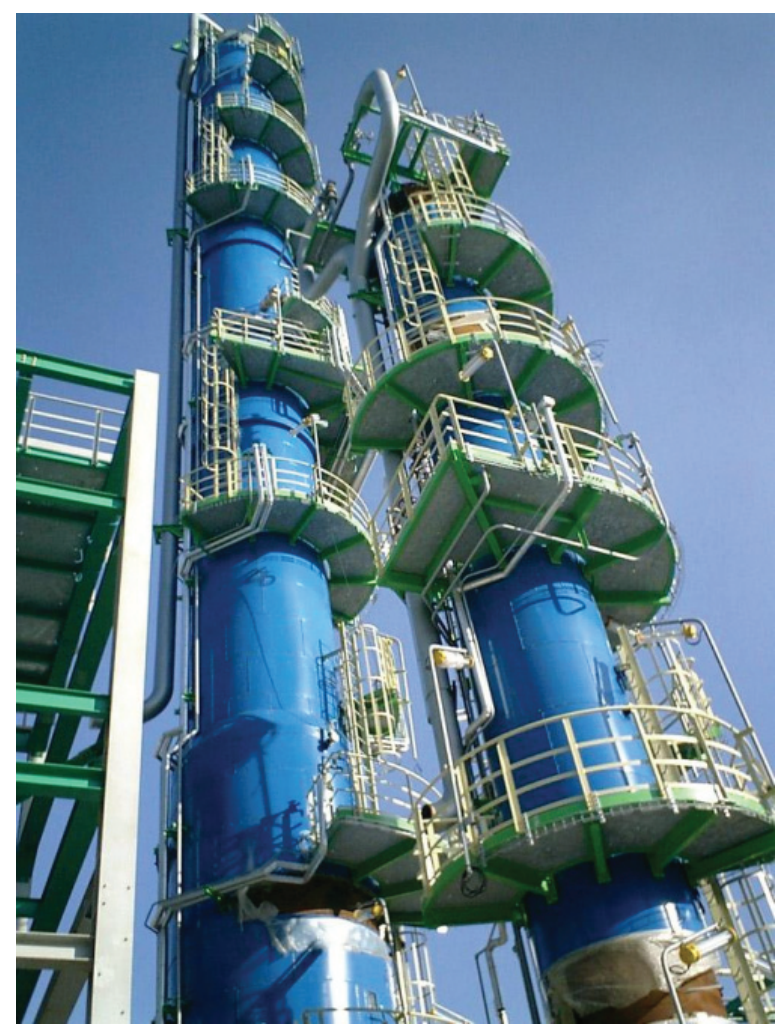

Figure 1. Gas Rectification Columns

The mechanical design basis of the gas rectification columns is presented in Table 1 .

Table 1. Technical data of the gas rectification columns

\begin{tabular}{||c|c||}
\hline Fabrication date 2003 & 2003 \\
\hline Design Pressure 7.9 MPa & $79 \mathrm{bar}$ \\
\hline Design Temperature & $100^{\circ} \mathrm{C}$ \\
\hline Weld Joint Efficiency & 0.85 \\
\hline Material of Construction & ASTM SA 516-70 \\
\hline Tensile strength & $482.63 \mathrm{MPa}$ \\
\hline Yield strength at $20^{\circ} \mathrm{C}$ & $262 \mathrm{MPa}$ \\
\hline Yield strength at $100^{\circ} \mathrm{C}$ & $239 \mathrm{MPa}$ \\
\hline Designed thickness & $82.4 \mathrm{~mm}$ \\
\hline Outside Diameter (OD) & $3064 \mathrm{~mm}$ \\
\hline Inside Diameter (ID) & $2900 \mathrm{~mm}$ \\
\hline Length & $31160 \mathrm{~mm}$ \\
\hline \multicolumn{2}{|c|}{}
\end{tabular}

Operating conditions allow aqueous conditions to occur with a localized measured corrosion rate of $0.33 \mathrm{~mm} / \mathrm{yr}$.

In addition, stress corrosion cracking caused by wet $\mathrm{H}_{2} \mathrm{~S}$ is possible with low susceptibility.

Inspection history from 2018 (B effectiveness level) revealed some localized corrosion and a measured thickness of $79.2 \mathrm{~mm}$.

No history of inspection for wet $\mathrm{H}_{2} \mathrm{~S}$ cracking has been conducted on these columns. 
The process fluid has the following properties:

$-\mathrm{C}_{6}-\mathrm{C}_{8}$,

- Density, $1050 \mathrm{~kg} / \mathrm{m} 3$,

- NBP $99^{\circ} \mathrm{C}$,

- Auto-Ignition Temperature; AIT $223^{\circ} \mathrm{C}$.

\section{Estimated Remaining Life}

The chemical composition of steel SA $516-70$ is listed in Table 2.

Table 2. Chemical composition of SA 516-70

\begin{tabular}{|c|c|c|c|c|c|c|c|c|c|c|c|c|c||}
\hline Composition & $\mathrm{C}$ & $\mathrm{Si}$ & $\mathrm{Mn}$ & $\mathrm{P}$ & $\mathrm{S}$ & $\mathrm{Al}$ & $\mathrm{Cr}$ & $\mathrm{Cu}$ & $\mathrm{Ni}$ & $\mathrm{Mo}$ & $\mathrm{Nb}$ & $\mathrm{Ti}$ & $\mathrm{V}$ \\
\hline \hline $\begin{array}{c}\text { Percentage } \\
\%\end{array}$ & $\begin{array}{c}0.10 / \\
0.22\end{array}$ & 0.6 & $1 / 1.7$ & 0.03 & 0.03 & 0.02 & 0.3 & 0.3 & 0.3 & 0.08 & 0.01 & 0.03 & 0.02 \\
\hline
\end{tabular}

The designed thickness of the absorber was $82.0 \mathrm{~mm}$, and wall thickness measured after years of service are presented in Fig. 3 which shows a graphical representation of the thinning of a cylindric wall.

Wall thickness is measured in 2020 to validate the results obtained in this work.

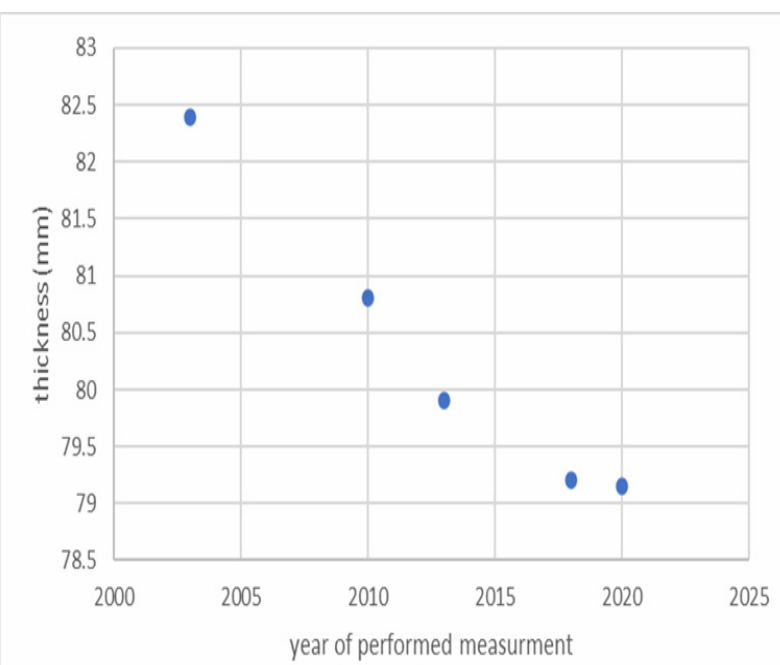

Figure 2. Graphical representation of wall thickness measured from 2003 to 2020

Thinning the cylindrical wall of Columns follows an exponential distribution, but it is expected that the corrosion rate will become linear after 20 years of service. [14].

Fig.3 shows the display of the ultrasonic thickness gauge.

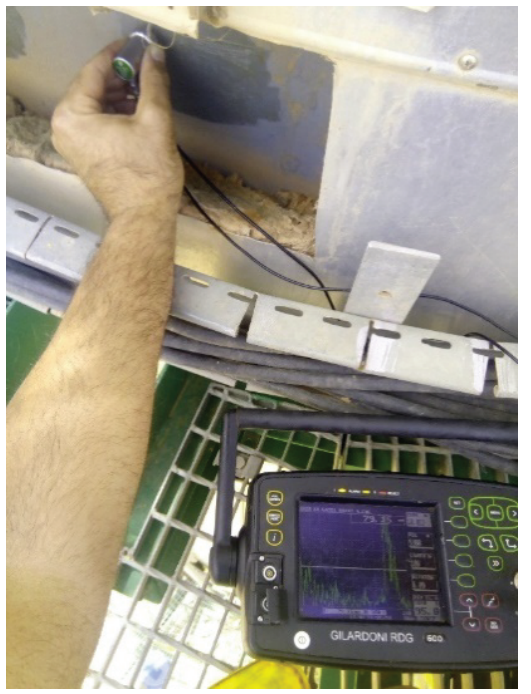

Figure 3. Display of ultrasonic thickness gauge during wall thickness measurement in 2020

The corrosion rate is calculated according to ASME [15, $16]$ in two ways: long time corrosion rate and short time corrosion rate according to the following equations:

$$
\frac{\text { Corrosion rate }(\mathrm{LT})=t_{\text {initial }}-t_{\text {actual }}}{\text { time between } t_{\text {initial }} \text { and } t_{\text {actual }}(\text { years })}
$$

$$
\frac{\text { Corrosion rate }(\mathrm{ST})=\left(t_{\text {previous }}-t_{\text {actual }}\right)}{\text { (time between } t \text { and } t \text { (years }))}
$$

Calculated corrosion rates are presented in Table 3.

Table 3. Corrosion rates [17]

\begin{tabular}{||c|c|c||}
\hline Type of Corrosion rate & $\mathrm{mm} / \mathrm{yr}$ & $\begin{array}{c}\text { time between } \\
\text { the measured values }\end{array}$ \\
\hline \hline $\mathrm{C}(\mathrm{LT})$ & 0.19 & 17 years \\
\hline $\mathrm{C}(\mathrm{LT})$ & 0.213333 & 15 years \\
\hline $\mathrm{C}(\mathrm{LT})$ & 0.25 & 10 years \\
\hline $\mathrm{C}(\mathrm{LT})$ & 0.1625 & 8 years \\
\hline $\mathrm{C}(\mathrm{ST})$ & 0.271429 & 7 years \\
\hline $\mathrm{C}(\mathrm{ST})$ & 0.2 & 5 years \\
\hline $\mathrm{C}(\mathrm{ST})$ & 0.36 & 3 years \\
\hline $\mathrm{C}(\mathrm{ST})$ & 0.025 & 2 years \\
\hline
\end{tabular}

Analyzing Table 3, it could be concluded that the short time corrosion rate is higher than the long time corrosion rate. For further calculation, the highest value of corrosion rate $(0.36 \mathrm{~mm} / \mathrm{yr})$ is taken as representative.

The corrosion rate has a decreasing tendency with increasing years in service.

A very important aspect of any pressure equipment is remaining life [18 - 20]. Remaining life estimation is the act of measuring and estimating the remaining lifespan of an appliance, for example, and a pressure vessel in oil and gas purification units. If the remaining life of the equipment or component can be known or estimated, the field engineer can perform the necessary maintenance and be able to plan the replacement of the piece of equipment [21]. The remaining life of the vessel (in years) shall be calculated from the following formula [22]:

$$
\text { Remaining life }=t_{\text {actual }}-t_{\text {required }} / \text { corrosion rate }
$$

Where:

- $t_{\text {actual }}$ is the actual thickness of a CML, in in. (mm), measured during the most recent inspection;

- $t_{\text {required }}$ is the required thickness at the same CML or component, in in. $(\mathrm{mm})$, as the actual measurement. It is computed by the design formulas (e.g. pressure and structural) and does not include corrosion allowance or manufacturer's tolerances [22].

Replacing the obtained results in equation (1) remaining life for Gas Rectification Columns is 15.72 years [17].

As per Plant Inspection Philosophy maximum interval is 2.5 years for PSV inspection which should be done by the Vendor or at specialist repair workshop approved by the Company according to $[23,24]$.

\section{Required column wall thickness depending on different safety factors}

Safety factors provide confidence in safe use of the pressure equipment components or assemblies. Pressure 
equipment is potentially dangerous in nature and safety factors ensure that the risk of breakage is minimized. Safety factors take into account uncertainties in design, materials, production, inspection, and even function. It is possible to identify three different types of safety factors. The first is technological uncertainty where the necessary data or a complete understanding of the process is lacking. Second, it is human error that is always present and includes human performance. The third is the accident, which, although a distant problem, must be taken into account. The safety factor is often seen as a factor of ignorance. It indicates the extent to which the designer or user does not have reliable data on the properties and performance of the material. Safety factors are generally considered to be a part of the design process.

Table 4 shows the required wall thicknesses of the cylindrical shell, without additives (corrosion additive, manufacturer's additives, tolerance, stability additive, etc.). Although the same formulas are used which include pressure, diameter, stresses, weld coefficient and degree of safety, different standards take into account different degrees of safety, i.e. allowable stresses, and thus large differences in the values of required wall thicknesses are obtained. Differences in the calculated required wall thicknesses are in some cases even over $50 \%$. The table gives an approximate difference in price, calculated for one meter of the cylindrical part of the vessel without openings or connections. The reference value is the ASME standard and the percentages expressed for other standards represent the higher price if it is recalculated according to that standard. On the other hand, the obtained larger wall thicknesses increase the life of the vessel, in this case, Gas Rectification Columns.

Table 4. Calculated required wall thickness according to different standards

\begin{tabular}{|c|c|c||}
\hline Standard & $\begin{array}{c}\text { required wall } \\
\text { thickness } \\
(\mathrm{mm})\end{array}$ & $\begin{array}{c}\text { Approximate difference in } \\
\text { price per meter related to } \\
\text { required wall thickness (\%) }\end{array}$ \\
\hline $\begin{array}{c}\text { ASME 2019, VIII, Division 1 } \\
\text { [16] }\end{array}$ & 61.54 & Ref value \\
\hline EN 13445 [25] & 87.14 & $40.97 \%$ \\
\hline AD 2000 Merkblatt [26] & 74.12 & $20.18 \%$ \\
\hline AS 1210 2010 [27] & 73.78 & $19.63 \%$ \\
\hline $\begin{array}{c}\text { BIS IS 2825: 1969 (R2017) } \\
{[28]}\end{array}$ & 87.11 & $40.92 \%$ \\
\hline DNVGL-RU-SHIP- & 92.44 & $49.40 \%$ \\
\hline Pt4Ch7[29] & 87.14 & $40.97 \%$ \\
\hline Codap 2005 [30] & 84.36 & $36.53 \%$ \\
\hline ГOCT 14249-89 [31] & & \\
\hline \hline
\end{tabular}

Since the introduction of safety regulations on the pressure systems that allow flexibility in adjusting the interval between inspections, users of pressure systems have become more interested in extending the interval of work between outages. Delaying or canceling inspections can result in significant savings. Although this may seem to reduce the level of safety, the practice is justified by the technological approach to risk analysis associated with the analysis of mechanisms and potential damage rates.

\section{Conclusion}

This paper presents the inspection of Gas Rectification Columns, determination, and analysis of remaining service life, corrosion rate, including the calculation of wall thickness according the various standards. From the presented the next could be concluded:
- Corrosion rate is extremely high. Short time corrosion rate is $0.36 \mathrm{~mm} / \mathrm{yr}$, a long time corrosion rates $0.25 \mathrm{~mm} / \mathrm{yr}$.

- The calculating remaining life is 18 years,

- Different safety factors affect the required wall thickness up to $49.40 \%$.

\section{Acknowledgment}

This research was financially supported by the Ministry of Education, Science and Technological Development of the Republic of Serbia, under the Contract number 451-039/2021-14/200105.

\section{References}

[1] MOKHATAB,S., POE,W.A., MAK,J.Y.: Handbook of Natural Gas Transmission and Processing - Principles and Practices, 4th edition, Elsevier, Cambridge, 2019.

[2] DEVOLD, H.: Oil and Gas Production Handbook-An introduction to oil and gas production, transport, refining and petrochemical industry, 3rd edition, ABB Industries, Oslo, 2013

[3] JARIĆ,M.S., MARTIĆ,I., BUDIMIR,N., SVETEL,I., MILANOVIĆ,M.: Total Costs of Shell and Tube Heat Exchangers with Concentric Helical Tube Coils, Thermal Science, 2019, Vol.23, No.6A, pp.3661-3673.

[4] BUDIMIR,N.J., JARIĆ,M.S., JAĆIMOVIĆ,B., GENIĆ,S., JAĆIMOVIĆ,N.: Rectified Ethanol Production Cost Analysis 282, Thermal Science, 2011, Vol.15, No.2, pp.281-292.

[5] DARLASTON,J., WINTLE,J., Safety factors in the design and use of pressure equipment, Engineering Failure Analysis, 2007, Vol.14 pp.471-480.

[6] SANDEEP,G.A., ANOOP,S., SHARMA.V., BIHARI,S.: Design and analysis of the pressure vessel, International Journal of scientific and engineering Research, 2004, Vol.4, No.5, pp.939-942.

[7] DEVARAJU,A., PAZHANIVEL,K.: A study on stress analysis for design of pressure vessel, International journal of mechanical and production engineering, 2015, Vol.3, No.11, pp.98-101.

[8] MERLIN,J.T., CHITARANJAN,P.: Design and analysis of pressure vessel with different end domes, International Journal of Science, Engineering and Technology Research, 2017, Vol.6, No.8, pp.12251233.

[9] RASHMIKHOBRAGADE, VINODHIWASE: Design and analysis of pressure vessel with hemispherical and flat circular end, International Journal of Engineering Science and Computing, 2017, Vol. 7 No. 5, pp. $12458-12469$.

[10] SADANANDAM,R., SAMUEL,T.: Design and Analysis of pressure vessel using finite element method, International journal of latest technology in engineering, management and applied science (IJLTEMAS), 2017, Vol.5, No.6, pp.1-3.

[11] APURVA,R.P., MAHESH,G., NITIN,D., RAJKUMAR,P.: Design and analysis of pressure vessel, International journal of innovative research in technology and science (IJIRTS), 2018, Vol. 3, No. 2, pp. 28-34.

[12] DURGA,P., SACHIDANANDA.H.K.: Design and analysis of pressure vessel, International Journal of Mechanical and Production Engineering Research and Development (IJMPERD) ISSN(P): 22496890, 2019, Vol.9, No.5, pp.125-136.

[13] KISTER,H.Z.: What caused tower malfunctions in the last 50 years?, Chemical Engineering Research and Design , 2003, Vol.81, No.1, pp.526.

[14] ISO 9224, Corrosion of metals and alloys. Corrosivity of atmospheres. Guiding values for the corrosivity categories, CEN, 2012.

[15] ASME SEC VIII, Division 1, 2019 ASME Boiler \&Pressure Vessel Code 2019, The American Society of Mechanical Engineers, 2019.

[16] ASME SEC VIII, Division 2: Alternative Rules, 2017 ASME Boiler \&Pressure Vessel Code 2017, The American Society of Mechanical Engineers, 2017.

[17] JARIĆ M., PETRONIĆ S., BUDIMIR N., ČOLIĆ K., JEREMIĆ L. Analysis of the estimated remaining service life of gas rectification columns, Thermal Science, 2021 , https://doi.org/10.2298/TSCI201214083J

[18] MARTIC,I, SEDMAK,A., TOMIC,R., HOT,I.: Remaining life determination for pressure vessel in a refinery, Structural Integrity and Life, 2016, Vol.16, pp.49-52. 
[19] ISHIZAKI,Y., YONEKAWA,F., YUMOTO,T., SUZUKI,T., HIJIKAWA,S.: Remaining life assessment of an external pressure vessel in creep range and inspection findings, Proceedings of the ASME 2017 Pressure Vessels and Piping Conference, PVP 2017, July 16-20, 2017, Waikoloa, Hawaii, USA.

[20] DEDOV,A., KLEVTSOV,I., LAUSMAA,T., HLEBNIKOV,A., BOJARINOVA,T.: Corrosion and life assessment of Intrex TM superheater tubes in a CFB oil shale boiler, Appl. Therm. Eng. (2016), http://dx.doi.org/doi: 10.1016/j.applthermaleng.2015.12.061.

[21] JAYANTO,S.T., CHENDRA,M., WIJAYANTA,A.T.: Estimating corrosion rate and remaining life of a pressure vessel of $\mathrm{H} 2 \mathrm{~S}$ absorber, AIP Conference Proceedings 2097, 2019. https://doi.org/10.1063/1.5098182

[22] ***, API PR 571, Damage Mechanisms Affecting Fixed Equipment in the Refining Industry, 3rd edition, American Petroleum Institute, 2020.

[23] ***, API 510, Pressure Vessel Inspector, American Petroleum Institute, 2020.

[24] ***, API 572, Inspection of Pressure Vessels, American Petroleum Institute, 2020.

[25] EN 13445, Unfired pressure vessels, CEN, 2014.
[26] AD 2000 Merkblatt B0: 2014, Design of pressure vessels, German Institute for Standardisation, 2014.

[27] AS 1210, Australian Standard Pressure Vessels, SAI Global Limited under licence from Standards Australia Limited, 2010. ISBN 9780 733796876.

[28] BIS IS 2825: 1969(R2017) Code for unfired pressure vessels, Bureau of Indian Standards, 2017.

[29] DNVGL-RU-SHIP-Pt4Ch7, Rules for classification: Ships, Pressure equipment, 2015 ed, https://rules.dnvgl.com/docs/pdf/DNVGL/RUSHIP/2015-10/DNVGL-RU-SHIP-Pt4Ch7.pdf, Access 03.11.2020.

[30] CODAP 2005, Division 1, Code for construction of unfired pressure vessels, Syndicat National De La Addendum, Chaudronnerie, Tolerie Et, 2007.

[31] ГОСТ 14249-89 Сосуды и аппараты, Нормы и методы расчета на прочность, (Vessels and apparatus. Norms and methods of strength calculation), 1989

\title{
Faktori sigurnosti u proračunu debljine zida kolona za rektifikaciju
}

\begin{abstract}
Kolone za rektifikaciju gasa veoma su važan deo svake fabrike. Njihovi iznenadni otkazi svakodnevno uzrokuju ogromne gubitke, dok curenje tečnosti može biti veoma opasno po ljude i životnu sredinu. Iz tog razloga, pravilan dizajn kolone je od velike važnosti, kao i primena ostalih faktora bezbednosti. $U$ ovom radu prikazano je merenje debljine zida sa ciljem da se izračuna stopa korozije i preostali vek trajanja rektifikacionih kolona. Minimalna potrebna debljina zida kolone izračunata je prema najčešće korišćenim međunarodnim standardima i analizirana je dobijena razlika.
\end{abstract}

Ključne reči: kolone za rektifikaciju gasa, faktori bezbednosti, stopa korozije, preostali vek trajanja, debljina, IBR. 